Seed quality and plantlet traits of perennial ryegrass after 5 years of seed storage at various temperatures

Svojstva klijanaca i biljaka engleskog ljulja nakon 5 godina skladištenja sjemena na različitim temperaturama

Bukvić, G., Gantner, R., Agić, D., Popović, B., Stanisavljević, A.

Poljoprivreda/Agriculture

ISSN: 1848-8080 (Online)

ISSN: 1330-7142 (Print)

http://dx.doi.org/10.18047/poljo.24.1.3

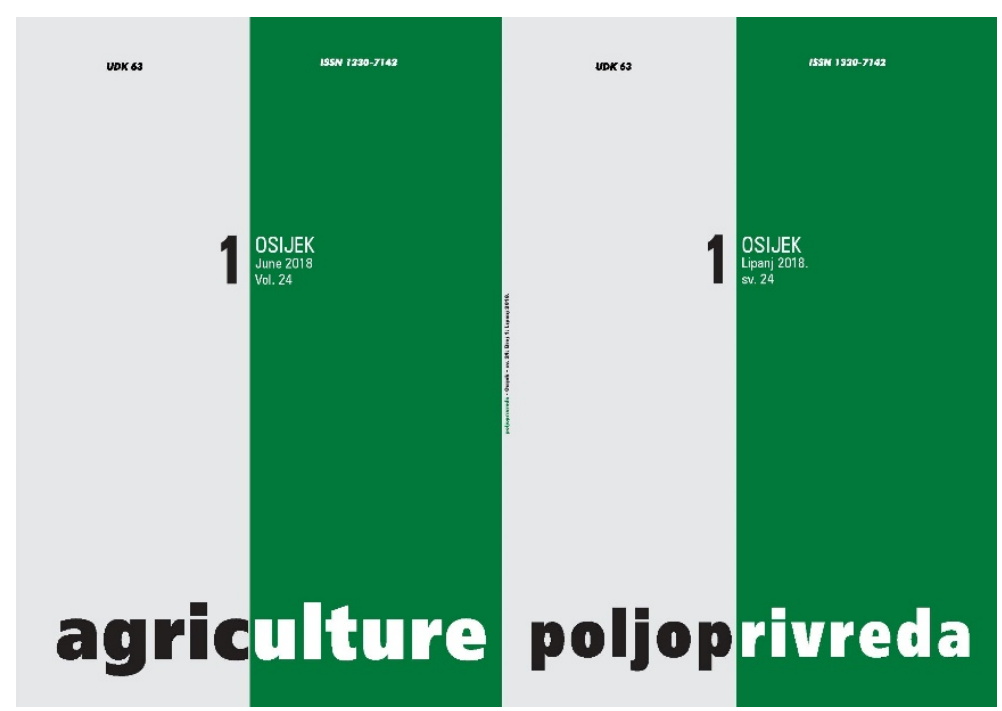

Poljoprivredni fakultet u Osijeku, Poljoprivredni institut Osijek

Faculty of Agriculture in Osijek, Agricultural Institute Osijek 
ISSN 1330-7142

UDK: 633.2:631.24

DOI: $10.18047 /$ poljo.24.1.3

\title{
SEED QUALITY AND PLANTLET TRAITS OF PERENNIAL RYEGRASS AFTER 5 YEARS OF SEED STORAGE AT VARIOUS TEMPERATURES
}

Bukvić, G., Gantner, R., Agić, D., Popović, B., Stanisavljević, A.

Original scientific paper

Izvorni znanstveni članak

\begin{abstract}
SUMMARY
The aim of this research was to investigate the seed quality of perennial ryegrass after 5-year storage treatments at various temperatures. The seeds of two cultivars of perennial ryegrass (diploid Bartwingo and tetraploid Calibra) were used, and the storage treatment temperatures were: room temperature (about $21^{\circ} \mathrm{C}$ ), $10^{\circ} \mathrm{C},-20^{\circ} \mathrm{C}$ and $-80^{\circ} \mathrm{C}$. Seed quality traits (germination and seedlings' root and shoot lengths) were determined before and after the storage treatments. Additionally, early development traits in mini-pots during the first two months of development (emergence, plantlet height, plantlet root length, fresh weight of roots and shoots) were tested. The research has shown significant effects of storage temperatures to all the investigated traits of seed quality and plantlets development. The highest average values for germination and seedling root and shoot lengths were obtained after the storage at $-80^{\circ} \mathrm{C}$, and the lowest after storage at room temperature. The highest average values for emergence, plantlet height and roots and shoots fresh weights were obtained after the storage at $-20^{\circ} \mathrm{C}$, while the root length was greatest after the storage at $-80^{\circ} \mathrm{C}$. Tetraploid cultivar Calibra had significantly greater average values than diploid Bartwingo for all the investigated traits except for germination and primary shoot length.
\end{abstract}

Key-words: perennial ryegrass, seed, storage temperature, cultivar

\section{INTRODUCTION}

Perennial ryegrass is one of the most important grasses in pasture mixtures. Generally, crop's yield and quality strongly depend on the quality of seed used for crop establishment. According to Marcos-Filho and McDonald (1998), seed quality is composed of its genetic, physical, physiological and health properties. Seed quality is largely influenced by the applied agronomy and environmental conditions during the seed crop's vegetation (McDonald, 1998), by seed processing (Schaffer and Vanderlip, 1999) and storage conditions and length of storing (Saxena et al., 1985).

Seed quality can be impaired during storage due to senescence (Vieira et al., 1999; Karaman et al., 2014), especially when stored in inadequate conditions. Optimal storage conditions depend on plant species whose seeds are to be stored. Critical factors in the storage, according to Elias et al. (2002) are: the kind of seed, seed moisture content, initial viability of seed, storage temperature and relative humidity, length of storage and protection from storage fungi and insects. Generally, grass seeds can better withstand storage than maize seeds, and maize seeds better than soybean seeds (Elias et al., 2002; Šimić et al., 2005). Seeds of small-seeded forages can maintain their vigor for a long period (Griffiths and Pegler, 1964; Rincker 1981; Lewis et al., 1998). Cattani (2007) reported that perennial ryegrass seeds with higher moisture content $(20 \%)$ and at higher temperatures $\left(25^{\circ} \mathrm{C}\right)$ lose their vigor sooner than seeds with lower moisture $(10.5 \%)$ and at lower temperatures $\left(5^{\circ} \mathrm{C}\right)$. Ching and Calhoun (1968) and Ching and Schoolcraft (1968) were investigating the

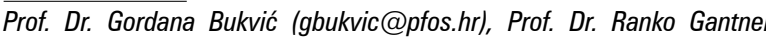
Assist. Prof. Dejan Agić, Prof. Dr. Brigita Popović, Prof. Dr. Aleksandar Stanisavljević - Josip Juraj Strossmayer, University of Osijek, Faculty of Agriculture in Osijek, Vladimira Preloga 1, 31000 Osijek, Croatia 
causes for loss of seed viability and vigor of crimson clover and perennial ryegrass seeds closed in tin cans during a 10 -year storage period with different seed moisture $(6$, $8,12,16$ and $20 \%)$ and at different temperatures $(3,22$ and $38^{\circ} \mathrm{C}$ ). They concluded that loss of viability and vigor was not due to depletion of food but there appeared to be rather related to the activity of proteases, phytase, and phosphatases, because an increase of permeability, amino acids, and inorganic phosphate was observed in the aged material. The magnitude of these increases was related to species, seed moisture and to a lesser degree to storage temperature. Besides seed moisture, temperature is the second most important factor of the seed lifespan and maintenance of germination (Justice and Bass, 1978; Vertucci and Roos, 1990; Vertucci and Roos, 1993). Seed germination testing is conducted according to standard germination method, i.e. in ideal conditions of moisture and temperature (Siddique and Wright, 2004), so the values of standard germination often surpass the field emergence (Hamman et al., 2002).

The aim of this research was to test the seed quality (in laboratory and field conditions) of two perennial ryegrass cultivars, stored for 5 years at different temperatures.

\section{MATERIAL AND METHODS}

Seeds of two perennial ryegrass cultivars were used for this research: Bartwingo and Calibra (Table 1).
Prior to the storage treatment, seed and seedling traits were tested, as shown in Table 2. Thereafter the seeds were stored in hermetically sealed glass jars at room temperature (about $21^{\circ} \mathrm{C}$ ), and at $10^{\circ} \mathrm{C},-20^{\circ} \mathrm{C}$ and $-80^{\circ} \mathrm{C}$ in climate chamber. Upon five years of storage, the seed traits (germination) and measured seedling traits (length of seedling roots and shoots) were tested. Seeds for germination testing were placed in rolled filter-paper in climate chamber according to ISTA rules (2003). Four replicates of 100 seeds per each temperature treatment were seeded.

The rest of the storage-treated seeds were simultaneously seeded in mini-pots in plastic container for the open-space examination. Pots were filled with commercial substrate, and seeded in four replicates for each temperature treatment. Containers were protected with metal web and covered with PVC foil when raining to protect against substrate erosion. Containers were watered with collected rainfall. During the vegetation, the emerged plants were counted, and upon 60 days they were pulled out for washing the roots, measurement of plant height and root length and for weighing aboveground herbage and roots. Statistics were performed using SAS Software-a 8.02. (Sas Institute, 2000). Differences between treatment means were tested by LSD test.

Table 1. Seed origin, thousand weight, moisture and ploidy level of tested perennial ryegrass seeds

Tablica 1. Podrijetlo, masa 1000 sjemenki, vlaga sjemena i ploidnost kultivara engleskoga ljulja

\begin{tabular}{|l|c|c|c|c|}
\hline $\begin{array}{l}\text { Cultivar } \\
\text { Kultivar }\end{array}$ & $\begin{array}{c}\text { Origin } \\
\text { Podrijetlo }\end{array}$ & $\begin{array}{c}\text { Thousand weight (g/1000 seeds) } \\
\text { Masa 1000 sjemenki (g) }\end{array}$ & $\begin{array}{c}\text { Moisture of seed (\%) } \\
\text { Vlaga sjemena (\%) }\end{array}$ & $\begin{array}{c}\text { Ploidy } \\
\text { Ploidnost }\end{array}$ \\
\hline Bartwingo & Netherlands/Nizozemska & 1.92 & 8.4 & diployd/diploid \\
\hline Calibra & Denmark/Danska & 3.06 & 10.4 & tetraployd/tetraploid \\
\hline
\end{tabular}

Table 2. Seed and seedling traits before the storage treatment

Tablica 2. Svojstva sjemena i klijanaca prije tretmana skladištenja

\begin{tabular}{|l|c|c|c|}
\hline $\begin{array}{l}\text { Cultivar } \\
\text { Kultivar }\end{array}$ & $\begin{array}{c}\text { Germination (\%) } \\
\text { Klijavost (\%) }\end{array}$ & $\begin{array}{c}\text { Seedlings root length (cm) } \\
\text { Dužina korijena klijanaca (cm) }\end{array}$ & $\begin{array}{c}\text { Seedling stem length (cm) } \\
\text { Dužina stabljike klijanaca (cm) }\end{array}$ \\
\hline Bartwingo & 85.8 & 5.28 & 8.11 \\
\hline Calibra & 68.5 & 6.52 & 9.33 \\
\hline
\end{tabular}

\section{RESULTS AND DISCUSSION}

Seeds of investigated perennial ryegrass cultivars had maintained their viability upon five years of storage treatment. Previous researches of Marsall and Lewis
(2004) and Ellis and Hong (2006) also showed that small seeded legumes and grasses can maintain their seed viability for long, over 10 years if stored at optimum moisture and storage conditions. Research of Rincker (1981) showed that some grass species seeds had ger- 
mination of $80 \%$ after 14 years of storage at $15^{\circ} \mathrm{C}$ and $60 \%$ relative air humidity.

When compared to the initial germination (Table 2), 5-year storage treatments significantly changed the germination (Table 3). Storage treatment at room temperature (about $20^{\circ} \mathrm{C}$ ) decreased the germination of Bartwingo cultivar by $69 \%$ and of Calibra cultivar by $52 \%$.

Table 3. Seed and seedling traits of two perennial ryegrass cultivars after the 5-year seed storage at various temperatures

Tablica 3. Svojstva sjemena i klijanaca kultivara engleskoga Ijulja nakon 5 godina skladištenja na različitim temperaturama

\begin{tabular}{|c|c|c|c|c|c|}
\hline \multirow{3}{*}{$\begin{array}{l}\text { Cultivar (C) } \\
\text { Kultivar (C) }\end{array}$} & \multicolumn{4}{|c|}{ Storage temperature (T) - Temperatura skladištenja (T) } & \multirow{2}{*}{$\begin{array}{l}\text { Average } \\
\text { Prosjek }\end{array}$} \\
\hline & $\mathrm{RT}^{*}$ & $10^{\circ} \mathrm{C}$ & $-20^{\circ} \mathrm{C}$ & $-80^{\circ} \mathrm{C}$ & \\
\hline & \multicolumn{5}{|c|}{ Seed germination (\%) - Klijavost sjemena (\%) } \\
\hline Bartwingo & 16.5 & 81.8 & 80.8 & 82.5 & 65.4 \\
\hline Calibra & 16.3 & 78.0 & 83.0 & 82.8 & 65.0 \\
\hline $\begin{array}{l}\text { Average } \\
\text { Prosjek }\end{array}$ & $16.4^{c}$ & $79.9^{b}$ & $81.9^{\mathrm{a}}$ & $82.6^{\mathrm{a}}$ & 65.2 \\
\hline LSD & $T^{* *}$ & C & $C \times T^{* *}$ & & \\
\hline 0.05 & 0.952 & Ns & 1.313 & & \\
\hline \multirow[t]{2}{*}{0.01} & 1.368 & Ns & 1.857 & & \\
\hline & \multicolumn{5}{|c|}{ Seedlings root length $(\mathrm{cm})$ - Dužina korijena klijanaca $(\mathrm{cm})$} \\
\hline Bartwingo & 1.87 & 5.06 & 5.26 & 5.38 & $4.39^{b}$ \\
\hline Calibra & 1.76 & 5.98 & 6.31 & 6.35 & $5.10^{\mathrm{a}}$ \\
\hline $\begin{array}{l}\text { Average } \\
\text { Prosjek }\end{array}$ & $1.81^{\mathrm{c}}$ & $5.52^{\mathrm{b}}$ & $5.78^{\mathrm{a}}$ & $5.87^{\mathrm{a}}$ & 4.75 \\
\hline LSD & $T^{* *}$ & $C^{* *}$ & $C \times T^{* *}$ & & \\
\hline 0.05 & 0.103 & 0.084 & 0.156 & & \\
\hline \multirow[t]{2}{*}{0.01} & 0.148 & 0.118 & 0.220 & & \\
\hline & \multicolumn{5}{|c|}{ Seedlings stem length $(\mathrm{cm})$ - Dužina stabljike klijanaca $(\mathrm{cm})$} \\
\hline Bartwingo & 2.07 & 5.45 & 5.77 & 6.14 & 4.86 \\
\hline Calibra & 1.98 & 5.90 & 5.04 & 6.28 & 4.80 \\
\hline $\begin{array}{l}\text { Average } \\
\text { Prosjek }\end{array}$ & $2.02^{\mathrm{d}}$ & $5.68^{\mathrm{b}}$ & $5.40^{c}$ & $6.21^{\mathrm{a}}$ & 4.83 \\
\hline LSD & $T^{* *}$ & C & $C \times T^{*}$ & & \\
\hline 0.05 & 0.117 & Ns & 0.159 & & \\
\hline 0.01 & 0.168 & Ns & 0.225 & & \\
\hline
\end{tabular}

${ }^{*} \mathrm{RT}$ - room temperature/sobna temperatura

Considering the lower temperatures of storage, they just slightly decreased the Bartwingo seeds germination (by only 3 to $5 \%$ ). Conversely, the lower storage temperatures have increased Calibra seeds germination (by 9.5 to $14.5 \%$ ). Increase or slight decrease of germination was previously reported by Ackigoz and Knowles (1983) after storage of crested wheatgrass, smooth bromegrass and intermediate wheatgrass seeds in glass jars upon 20 years of stor- age at -7 and $-18^{\circ} \mathrm{C}$. In their research seeds stored at higher temperatures $\left(1.5\right.$ and $\left.21^{\circ} \mathrm{C}\right)$ have lost their germination. Research of Bean et al. (1984) showed higher perennial ryegrass germination after 3 to 5 years of storage in aluminum foil with $5 \%$ moisture and at temperatures -25 and $0^{\circ} \mathrm{C}$ when compared to storage at $18^{\circ} \mathrm{C}$. Stanisavljević et al. (2010) observed an increase of germination of tall oat-grass seeds after 150 to 240 days of storage. 
When averaged over cultivars, germination differed significantly between temperature treatments (Table 3). The highest germination was associated with the lowest storage temperatures, i.e. at -20 and $-80^{\circ} \mathrm{C}$, and the poorest with the room temperature. These results were in accordance with previous research of Bukvić et al. (2015). When averaged over storage temperature levels, cultivars did not differ significantly. However, significant differences between cultivars upon the storage at 10 and $-20^{\circ} \mathrm{C}$ were observed. Cultivar Bartwingo had greater germination upon storage at $10^{\circ} \mathrm{C}$ and Calibra upon $-20^{\circ} \mathrm{C}$.

Seedlings root length depended significantly $(p<0.01)$ on seed storage temperature, cultivar and their interaction (Table 3). The shortest seedling root length was obtained after storage at room temperature, and the longest at $-80^{\circ} \mathrm{C}$, which was in line with Bukvić et al. (2015) research. When averaged over cultivars, difference in root length between storage at -20 and -80 ${ }^{\circ} \mathrm{C}$ was not significant.

Calibra cultivar exhibited generally longer seedling root length than Bartwingo, except upon storage at room temperature, which was in line with previous work of Bukvić et al. (2015). Considering the root lengths, the greatest difference between cultivars was obtained upon storage at $-20^{\circ} \mathrm{C}$.

Storage treatments slightly decreased the seedling root length when compared to the initial values obtained before treatment, except storage below $0^{\circ} \mathrm{C}$. Slight decrease in seedling root length was previously reported by Stanisavljević et al. (2010) for tall oat-grass after 690 days of storage.

Seedlings shoot length significantly depended on storage temperatures and on interaction between temperature and cultivar $(p<0.01)$, but cultivars did not differ significantly. The longest seedling shoot length was obtained upon storage temperature $-80^{\circ} \mathrm{C}$, and the shortest upon storage at room temperature. Statistically significant differences between cultivars $(p<0.01)$ for seedling shoot length were observed upon storage temperatures of 10 and $-20^{\circ} \mathrm{C}$. Bartwingo cultivar had greater values upon storage at $10^{\circ} \mathrm{C}$ and Calibra upon $-20^{\circ} \mathrm{C}$.

When compared to the initial shoot lengths, storage treatments considerably decreased the values. Conversely, Stanisavljević et al. (2011) did not reveal any significant seedling shoot length decrease after 990 days of seed storage.

Plantlets emergence was significantly influenced $(p<0.01$.) by storage temperature, cultivar and their interactions (Table 4.). The highest average emergence was observed from seeds stored at $-20^{\circ} \mathrm{C}$, and the least at room temperature. Generally, Calibra cultivar had greater emergence than Bartwingo. Plantlet emergence differed between cultivars significantly at all the investigated temperatures. Bartwingo had greater emergence only upon storage temperature at $10^{\circ} \mathrm{C}$. However, the greatest emergence for Calibra was observed upon the $-20^{\circ} \mathrm{C}$ storage treatment and for Bartwingo upon the $10^{\circ} \mathrm{C}$ storage treatment. Greatest differences in emergence between cultivars were observed upon $-20^{\circ} \mathrm{C}$ storage treatment, and the least upon $-80^{\circ} \mathrm{C}$.

Plantlet heights were significantly lower upon the room temperature storage treatment when compared to the other temperatures $(p<0.01)$, and Calibra had generally higher plantlet height than Bartwingo. However, significant difference between cultivars was not observed only upon storage at $-20^{\circ} \mathrm{C}$.

Plantlet root length was significantly $(p<0.01)$ affected by storage temperature treatments, genotype and their interaction (Table 4). Plantlet root length was greatest upon the storage at $-80^{\circ} \mathrm{C}$ and shortest upon room temperature. Calibra cultivar had greater root length $p<0.01$ than Bartwingo upon all storage temperature treatments except $10^{\circ} \mathrm{C}$. Generally greater root length could be due to the tetraploidy of Calibra cultivar and consequently with greater seed mass (Evans, 1970). Deru et al. (2012) obtained greater root length and mass for mowed perennial ryegrass than for grazed one, regardless of the cultivar ploidy level. Their research was conducted with 4 diploid and 4 tetraploid cultivars. The greatest difference between cultivars was observed upon $-20^{\circ} \mathrm{C}$ storage and the least upon $10^{\circ} \mathrm{C}$.

Aboveground fresh weight for both cultivars was greatest upon storage at $-20^{\circ} \mathrm{C}$ and the least upon room temperature storage treatment (Table 4). Cultivar Calibra had greater values at all the storage temperature treatments, and in general average significantly greater than Bartwingo $(p<0.01)$. Greatest difference between cultivars was observed upon storage at $-80^{\circ} \mathrm{C}$ and least upon the storage at room temperature.

Plantlets' root fresh weight was significantly affected $(p<0.01)$ by storage temperature treatments, cultivar and their interaction.

When averaged over cultivars, the greatest plantlet root fresh weight was obtained upon storage at $-20^{\circ} \mathrm{C}$ but cultivar Bartwingo had the greatest value upon -80 ${ }^{\circ} \mathrm{C}$. The lowest root fresh weights were observed upon storage at room temperature. Tetraploid cultivar Calibra had higher values upon storage at all temperatures except at the room temperature $(p<0.01)$. Deru et al. (2014), in two field trials, identified different effect of ploidy level to the perennial ryegrass root dry matter mass and length. The greatest differences in root weight between cultivars were observed upon the storage at $-20^{\circ} \mathrm{C}(4.28 \mathrm{~g})$ and least upon $10^{\circ} \mathrm{C}(0.64 \mathrm{~g})$

High seed germination after 5 years of storage, especially at -20 and $-80^{\circ} \mathrm{C}$ resulted in high values of seedlings and plantlets traits. Significant positive correlations between germination and seedling and plantlet traits were identified (Table 5). 
Table 4. Emergence and plantlet traits of two perennial ryegrass cultivars after the 5 years of seed storage at various temperatures

Tablica 4. Nicanje i svojstva biljaka dvaju kultivara engleskoga ljulja nakon 5 godina skladištenja sjemena na različitim temperaturama

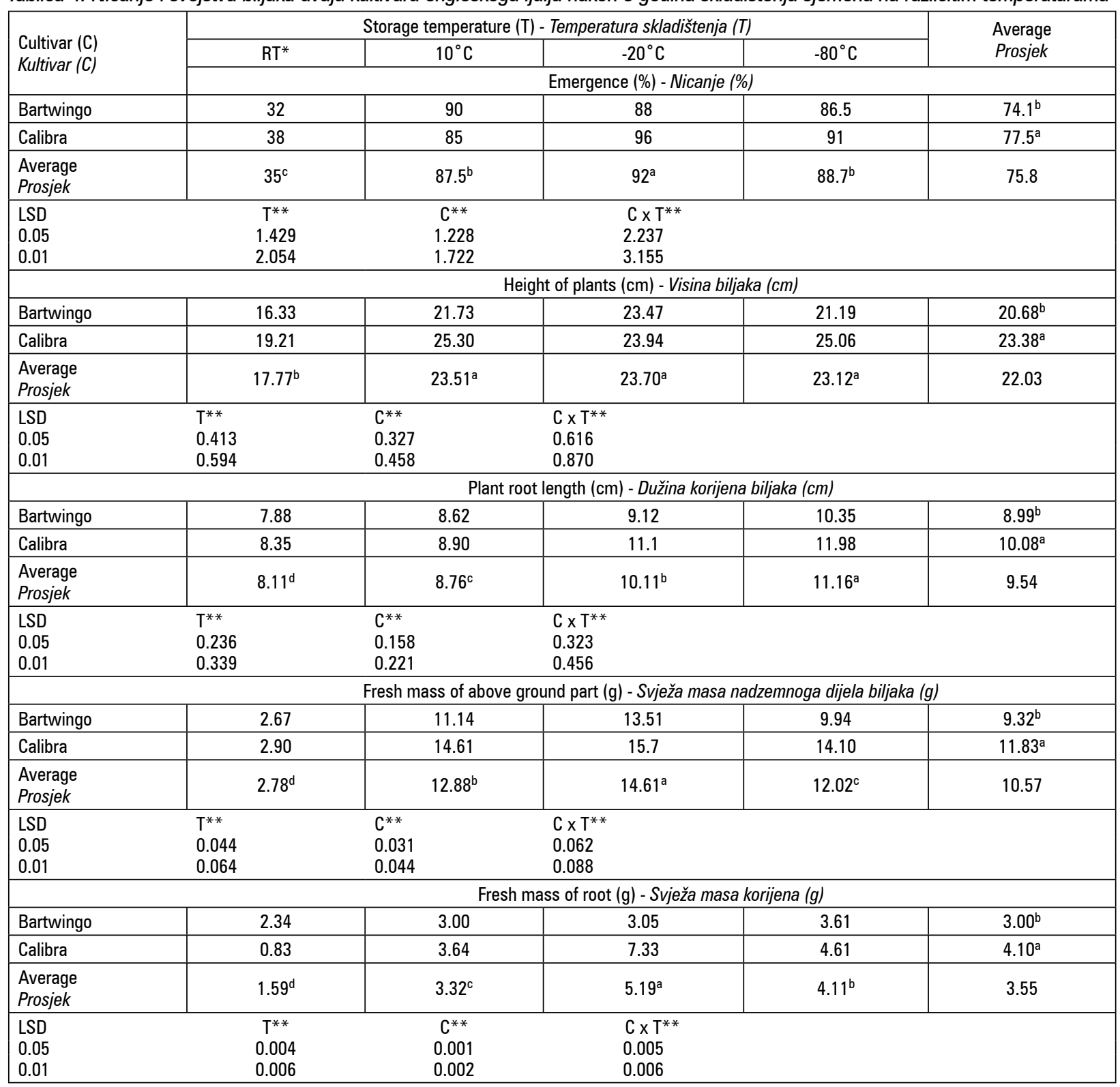

${ }^{*} \mathrm{RT}$ - room temperature/sobna temperatura

Table 5. Correlation coefficients between investigated seed, seedling and plantlet traits of perennial ryegrass cultivars Tablica 5. Koeficijenti korelacije između ispitivanih svojstava sjemena, klijanaca i biljaka kultivara engleskog ljulja

\begin{tabular}{|l|c|c|c|c|c|c|c|c|}
\hline & E & PH & PRL & PSFW & PRFW & SG & SRL & SSL \\
\hline E & - & $0.889^{* *}$ & $0.728^{*}$ & $0.982^{* *}$ & $0.923^{* *}$ & $0.994^{* *}$ & $0.984^{* *}$ & $0.971^{* *}$ \\
PH & - & - & 0.665 & $0.942^{* *}$ & 0.629 & $0.877^{* *}$ & $0.912^{* *}$ & $0.856^{* *}$ \\
PRL & - & - & - & $0.780^{*}$ & $0.777^{*}$ & $0.833^{*}$ & $0.846^{* *}$ & $0.796^{*}$ \\
\hline PSFW & - & - & - & - & $0.823^{*}$ & $0.995^{* *}$ & $0.989^{* *}$ & $0.984^{* *}$ \\
\hline PRFW & - & - & - & - & - & $0.799^{*}$ & $0.895^{* *}$ & $0.859^{* *}$ \\
\hline SG & - & - & - & - & - & - & $0.988^{* *}$ & $0.989^{* *}$ \\
\hline SRL & - & - & - & - & - & - & - & $0.978^{* *}$ \\
\hline SSL & - & - & - & - & - & - & - & - \\
\hline
\end{tabular}

E - emergence/nicanje; PH - plantlet height/visina biljaka; PRL - plantlet root length/dužina korijena biljaka; PSFW - plantlet shoot fresh weight/svježa masa nadzemnoga dijela biljaka; PRFW - plantlet root fresh weight/ svježa masa korijena; SG- seed germination/klijavost sjemena; SRL - seedling root length/ dužina korijena klijanaca; SSL - seedling shoot length/dužina stabljike klijanaca 


\section{CONCLUSION}

Based on the 5-year seed storage temperature treatments, the following was identified:

- Germination and seedling traits had greatest values upon storage at $-80^{\circ} \mathrm{C}$, but these values did not differed significantly from those obtained upon storage at $-20^{\circ} \mathrm{C}$;

- Seedling and plantlet traits had lowest values upon storage at room temperature;

- Emergence and plantlet root and shoot fresh weight and highest average values upon storage at $-20^{\circ} \mathrm{C}$, plantlet root length was greatest upon $-80^{\circ} \mathrm{C}$ and plantlet height was higher upon 10 , -20 and $-80^{\circ} \mathrm{C}$ than upon storage at room temperature;

- Tetraploid cultivar Calibra has shown grater values of all the investigated traits than diploid cultivar Bartwingo $(p<0.01)$, except for germination and seedling shoot length.

The research has proven that long term storage of seeds deteriorates seed quality, even in optimum storage conditions. Loss of quality will depend on plant species, genotype and ploidy level, with consequences for laboratory tests results and field performance.

\section{REFERENCES}

1. Ackigoz, E., \& Knowles, R. P. (1983). Long-term storage of grass seeds. Canadian Journal of Plant Science,63(3), 669-674. https://doi.org/10.4141/cjps83-084

2. Bean, E. W., Sengul, S., \& Tyler, B. F. (1984). The germination of grass seeds after storage at different temperatures in aluminium foil and manilla paper packets. Annals of Applied Biology, 105(2), 399-403. https://doi. org/10.1111/j.1744-7348.1984.tb03065.x

3. Bukvić, G., Gantner, R., Grljušić, S., Popović, B., Agić, D., \& Stanisavljević, A. (2015). Effects of storage period and temperature upon seed and seedling traits of perennial ryegrass (Lolium perenne L.). Poljoprivreda, 21(2), 3-9. http://doi.org/10.18047/polj.21.2.1

4. Cattani, D. (2007). Perennial ryegrass seed production. In Proc. 8thAnnual Manitoba Agronomists Conference.

http://www.umanitoba.ca/faculties/afs/MAC_proceedings/proceedings/2007/Doug_Cattani.pdf

5. Ching, T. M., \& Calhoun, W. (1968). Productivity of 10-Year-Old Canned Forage Seeds 1. Agronomy Journal, 60(4), 393-394. https://doi.org/10.2134/ agronj968.00021962006000040018X

6. Ching, T. M., \& Schoolcraft, I. (1968). Physiological and Chemical Differences in Aged Seeds 1. Crop Science, 8(4), 407-409. https://doi.org/102135/cropsci1968.001 $1183 \times 000800040003 \mathrm{x}$

7. Deru, J., Van Eekeren, N., \& De Boer, H. (2012). Rooting density of three grass species and eight Lolium perenne cultivars. Grassland Science in Europe, 17, 604-606. http://www.louisbolk.org/downloads/2618.pdf
8. Deru, J., Schilder, H., van der Schoot, J. R., \& van Eekeren, N. (2014). Genetic differences in root mass of Lolium perenne varieties under field conditions. Euphytica, 199(1-2), 223-232. https://doi.org/10.1007/ s10681-014-1129-x

9. Elias, S., Garay, A., Young, B., \& Chastain, T. (2002). Maintaining seed viability in storage: A brief review of management principles with emphasis on grass seeds stored in Oregon. Technical Brochures. Seed Laboratory at Oregon State University. http://seedlab.oregonstate. edu/maintaining-grass-seed-viability-storage

10. Ellis, R. H., \& Hong, T. D. (2006). Temperature sensitivity of the low-moisture-content limit to negative seed longevity-moisture content relationships in hermetic storage. Annals of Botany, 97(5), 785-791. https://doi. org/10.1093/aob/mcl035

11. Evans, P. S. (1970). Root growth of Lolium perenne L. 1. Effect of plant age, seed weight, and nutrient concentration on root weight, length, and number of apices. New Zealand Journal of Botany, 8(3), 344-356. https://doi.org $/ 10.1080 / 0028825 X .1970 .10429134$

12. Griffiths, D. J., \& Pegler, R. A. D. (1964). The effects of long-term storage on the viability of S23 perennial ryegrass seed and on subsequent plant development. Grass and Forage Science, 19(2), 183-190. https://doi. org/10.1111/j.1365-2494.1964.tb01160.x

13. Hamman, B., Egli, D. B., \& Koning, G. (2002). Seed vigor, soilborne pathogens, preemergent growth, and soybean seedling emergence. Crop Science, 42(2), 451-457. https://doi.org/10.2135/cropsci2002.4510

14. ISTA Rules, 2003. International Association for Seed Testing.

15. Justice, O. L., \& Bass, L. N. (1978). Principles and practices of seed storage. US Dept. of Agriculture, Science and Education Administration. https://naldc.nal.usda. gov/download/CAT87208646/PDF

16. Karaman, S., Toker, Ö. S., Öztürk, İ., Yalcin, H., Kayacier, A., Doğan, M., \& Sağdiç, 0. (2014). A response surface methodology study on the effects of some phenolics and storage period length on vegetable oil quality: change in oxidation stability parameters. Turkish Journal of Agriculture and Forestry, 38(6), 759-772. https://doi. org/10.3906/tar-1403-98

17. Lewis, D. N., Marshall, A. H., \& Hides, D. H. (1998). Influence of storage conditions on seed germination and vigour of temperate forage species. Seed Science and Technology, 26(3), 643-655.

18. Marcos-Filho, J., \& McDonald, M. B. (1998). Sensitivity of RAPD analysis, germination and vigour tests to detect the intensity of deterioration of naturally and artificially aged soybean seeds. Seed Science and Technology, 26(1), 141-157.

19. Marshall, A. H., \& Lewis, D. N. (2004). Influence of seed storage conditions on seedling emergence, seedling growth and dry matter production of temperate forage grasses. Seed Science and Technology, 32(2), 493-501. https://doi.org/10.15258/sst.2004.32.2.19

20. McDonald, M. B. (1998). Seed quality assessment. Seed Science Research, 8(2), 265-276.

https://doi.org/10.1017/S0960258500004165 
21. Rincker, C. M. (1981). Long-Term Subfreezing Storage of Forage Crop Seeds 1. Crop science, 21(3), 424-427. https://doi.org/10.2135/cropsci1981.0011183X0021000 $30017 x$

22. SAS Institute (2000): SAS/STAT User`s guide version 8. SAS Institute Inc., Cary, NC.

23. Saxena, 0. P., Singh, G., Pakeeraiah, T., \& Pandey, N. (1985). Seed deterioration studies in some vegetable seeds. Seed Research in Horticulture 215, 39-44 https://doi.org/10.17660/ActaHortic.1987.215.5

24. Schaffer, V. A., \& Vanderlip, R. L. (1999). The effect of conditioning on soybean seed quality. Journal of Production Agriculture, 12(3), 455-459. https://doi. org/10.2134/jpa1999.0455

25. Siddique, A. B., \& Wright, D. (2004). Effects of date of sowing on seed yield, seed germination and vigour of peas and flax. Seed Science and Technology, 32(2), 455472.

https://doi.org/10.15258/sst.2004.32.2.16

26. Stanisavljević, R., Djokić, D., Milenković, J., Terzić, D., Djukanović, L., Stevović, V., \& Dodig, D. (2010). Desiccation, postharvest maturity and seed aging of tall oat-grass. Pesquisa Agropecuária Brasileira, 45(11), 1297-1302.

https://doi.org/10.1590/S0100-204X2010001100010
27. Stanisavljevic, R., Đjokic, D., Milenkovic, J., Đukanovic, L., Stevovic, V., Simic, A., \& Dodig, D. (2011). Seed germination and seedling vigour of Italian ryegrass, cocksfoot and timothy following harvest and storage. Ciencia e agrotecnologia, 35(6), 1141-1148. https://doi.org/10.1590/S1413-7054211000600014

28. Šimić, B., Vratarić, M., Sudarić, A., Krizmanić, M., \& Andrić, L. (2005). Effect of storage longevity un26+der different storage conditions on seed vigor and oil content in maize, soybean and sunflower. Poljoprivreda, 11(2), 12-17.

29. Vertucci, C. W., \& Roos, E. E. (1990). Theoretical basis of protocols for seed storage. Plant Physiology, 94(3), 1019-1023. https://doi.org/10.1104/pp.94.3.1019

30. Vertucci, C. W., \& Roos, E. E. (1993). Theoretical basis of protocols for seed storage II. The influence of temperature on optimal moisture levels. Seed Science Research, 3(3), 201-213. https://doi.org/10.1017/ S0960258500001793

31. Vieira, R. D., Paiva-Aguero, J. A., Perecin, D., \& Bittencourt, S. (1999). Correlation of electrical conductivity and other vigor tests with field emergence of soybean seedlings. Seed Science and Technology, 67-75.

\section{SVOJSTVA KLIJANACA I BILJAKA ENGLESKOG LJULJA NAKON 5 GODINA SKLADIŠTENJA SJEMENA NA RAZLIČITIM TEMPERATURAMA}

\section{SAŽETAK}

Istraživanja su provedena s ciljem uturđivanja kvalitete sjemena engleskoga ljulja skladištenoga 5 godina na različitim temperaturama. Korišteno je sjeme dvaju kultivara (diploid Bartwingo i tetraploid Calibra), koje je skladišteno na sobnoj te na temperaturama $10,-20 \mathrm{i}-80^{\circ} \mathrm{C}$. Prije i nakon skladištenja u klima komori utvrđena su svojstva sjemena i klijanaca (klijavost, dužine korijena i stabljike klijanaca). Također, nakon skladištenja, sjeme je posijano u kontejnere od stiropora. Određeno je nicanje, a nakon 2 mjeseca svojstva biljaka: visina, dužina korijena, svježa masa korijena i nadzemnoga dijela. Dobiven je značajan utjecaj temperature na sva ispitivana svojstva sjemena, klijanaca i biljaka. U prosjeku za kultivare najveće vrijednosti za klijavost sjemena, dužinu korijena i stabljike klijanaca dobivene su kod sjemena skladištenoga na $-80^{\circ} \mathrm{C}$, a najniže skladištenjem na sobnoj temperaturi. Najveće prosječne vrijednosti za nicanje, svježu masu korijena i nadzemnoga dijela biljaka dobivene su sjetvom sjemena skladištenoga na $-20^{\circ} \mathrm{C}$; visina biljaka bila je najmanja od sjemena skladištenoga na sobnoj temperaturi, a između ostalih vrijednosti nije bilo razlike. Dužina korijena bila je najveća sjetvom sjemena skladištenoga na $-80^{\circ} \mathrm{C}$. Nicanje, dužina korijena, svježa masa korijena i nadzemnoga dijela bile su najniže na sobnoj temperaturi. Tetraploidni kultivar Calibra imao je značajno veće prosječne vrijednosti za sva ispitivana svojstva, osim klijavosti sjemena i dužene stabljike klijanaca.

Ključne riječi: engleski ljulj, skladištenje, temperatura, kultivar

(Received on 29 March 2018; accepted on 7 May 2018 - Primljeno 29. ožujka 2018.; prihvaćeno 07. svibnja 2018.) 